\title{
Role of Stakehoders in Implementing Green Supply Chain Practices in Indian Automobile Industry
}

\author{
Renu Paisal ${ }^{1}$ \\ Dr. Manisha Sharma ${ }^{2}$
}

\begin{abstract}
Effulgence
Vol. 15 No. 2

July-December, 2017

Rukmini Devi Institute of Advanced Studies

E-mail : effulgence@rdias.ac.in, Website : www.rdias.ac.in

http://effulgence.rdias.ac.in/user/default.aspx

https://dx.doi.org/10.33601/effulgence.rdias/v15/i2/2017/17-32
\end{abstract}

\begin{abstract}
Concerned with environmental sustainability, most organizations have started to go green in their functions and are adopting green supply technology in order to provide more benefit to their business operations as well as their suppliers and customers. Environmental concerns have become very important issues mainly in manufacturing industry for obvious reasons and more so in the automobile industry as it is considered to be one of the biggest sources of pollution. It is observed by many researchers that stakeholders play key roles in a number of ways in the supply chain. Therefore, this study specifically aims at understanding the role of stakeholders in the implementation of Green Suuply Chain Practices (GSCP) in Indian Automobile Industry. The present paper is qualitative in nature which will explore various research papers extensively to bring out the nature of relationship which can be tested further empirically.
\end{abstract}

Keywords: Green Supply Chain Practices, Stakeholders, Indian Automobile Industry

\section{INTRODUCTION}

Supply chain management implies the coordination and management of the entire network of activities concerned in delivering a finished product to the end-user or customer. As described by Womack and Jones, (2005) supply chain management is the key component of organizational competitiveness and effectiveness. There has been increasing pressure on industries to pay more attention to the environmental concern of the everincreasing production, supply and consumption of consumer goods and services. As a result the integration of environment and sustainability within supply chain management agenda has gained immense importance (Kleindorfer et al., 2005). Subsequently, companies are being required to address questions about how eco friendly their manufacturing processes and supply chains are. As Vachon and Klassen (2006) points out that complex and long supply chains are not energy efficient as they pose a potential threat to the environment due to excessive use of waste material which results in heat emission.

1. Research Scholar, Gautam Buddha University, Greater Noida (India), renu.paisal@gbu.ac.in

2. Assistant Professor, Gautam Buddha University, Greater Noida (India), manisha@gbu.ac.in

Corresponding Author

Dr. Manisha Sharma, Assistant Professor, Gautam Buddha University, Greater Noida (India), manisha@gbu.ac.in 
Supply Chains have been defined as a "network of organizations which are involved, through upstream and downstream links, in various processes and activities that produce value in the form of products and services in the hands of the final consumer" by Christopher (1998). In other words, it is the summation of endeavors to integrate a network of firms and coordination of their functions as regards information, material and financial flows. This has caused change of focus from reducing operational costs and overall inventory to improved customer service and speedy product delivery. Worldwide interest in supply chain management has increased steadily since two decades as organizations begin to see benefits of collaborative relationships in business and operations. Stevenson (2007) has noticed that Supply chains have involved into effective network of organizations performing activities in a particular product/service value chain". Organizations in a supply chain divide up the benefits of the product through market, contracts, and partnership which increase the efficiency of all partners. In today's complex economy, the competition among large firms has long been extended to the competition in major parts of supply chains. As explained by Soni and Kodali (2011), "Supply chain practices include internal and external issues that must be tailored to be a 'strategic fit' between competitive strategy and supply chain strategy of the company in order to achieve business excellence". As with all industries, business environmental factors and Government regulations affect supply chain to a very large extent followed by costing and buyer-supplier relationship. In Indian context, as cost of raw materials and labour are nearly same across the auto component manufacturing sector, they hardly bear any competitive advantage. Fisher (1997) stated that a supply chain must be designed based on specific requirements of the product being manufactured. This is especially for the complex automotive industry wherein, an automaker has to accept the challenges of managing a network comprising several supply chains specializing in sub-assemblies or modules and over thousands of components obtained from a variety of sources. It is essential that
Indian auto industry aligns supply chain practices to business strategy to maximize competitive benefit in a rising market. However, prior to economic liberalization (1991), supply chain management had not been seen as a competitive advantage due to protected tariffs, import quotas, exchange rate controls and regulated licensing for capital goals. All these safeguard policies dispirited modernization, cost effectiveness, and achievement of industrial capabilities thereby causing inefficiencies, sluggish export performances, and slow economic growth rate. However post liberalization era, quantum leap was observed in economic growth, which reflected in the Indian industries', including that of automotive industry, improved capability of effectively managing their supply chains (Sahay et al., 2003). This resulted from an understanding that existing supply chain systems were not developed enough to meet the growing requirements of consumers (Kapoor and Ellinger, 2004).

Nevertheless, even though the foremost global supply chain challenges viz visibility, cost containment, hazard management, growing customer demands and globalization remain the same, in the Indian context, their impact is distinctly different from those in developed countries. Indian market has some peculiar challenges for supply chains which they have to cope with like for Indians first preference is small cars and two wheelers. There is absolutely no visibility of customers especially in rural segment of markets. Lingual as well cultural diversities add to packaging complexities. Resource shortcomings cause quality related issues. Large number of fragmented and scattered suppliers are also big impediment in effective collaborations.

Multiplicity of taxes and tariffs, lack of infrastructure, multilevel distribution system, which effects products price, weak intellectual property and patent laws, poor standard of contract enforcement agencies, variation in cost and availability of raw material supplies are to name a few in Indian context. Multinational companies entering India never faced challenges like cultural 
diversities; price-income disparities and sourcing are unique to multinational companies that enter India.

Besides these factors, stiff competitive environment coupled with volatile demand and changing customer preferences, has led the industry to realize that therefore, the automotive supply chain has to be responsive. As attaining flexible practices are adversely impacted by a host of other factors such as global economic instability, identifying and adapting to promising markets, rising competitive rivalries and consumer preferences etc, Automakers are focusing on effectiveness of the total supply chain rather than on upgrading the specific functional areas, assimilation of product development process with the production system, the essentials of which involve close, frequent, interactions both informally as well as formally between employees and close mentoring of subordinates by the supervisors.

\section{Green Supply Chain Practices (GSCP): A review}

The term 'GSCP' refers to a variety of activities performed by an organization that helps minimize the impact on the environment (Vachon and Klassen, 2006; Sarkis et al., 2010). In recent years the idea has been to integrate the green process into the existing supply chain structure metrics and best practices that not only advance the environmental management but also increase value to the business (Nwe et al., 2010). The process of integration of environmental and sustainability concerns within supply chain management has itself evolved into a separate and growing field, having a varied set of names as such : sustainable supply network management, supply chain environmental management, green purchasing and procurement, environmental purchasing, green logistics, environmental logistics and sustainable supply chains (Sarkis, 2012).

However, the research and investigation on external policies and practices suggested by Hoejmose and Adrien-Kirby (2012) such as Sustainable Supply Chain Management (SSCM) practices, and organizational economic performance has been receiving relatively less attention in the literature. Much of the literature in this area has utilized a multiplicity of actions that are normally selfreported, from a single resource, and has focused on either environmental or social sustainability separately (Seuring and Muller, 2008). Expanding on these limitations, a further understanding of the effects of supply chain green practices, including social, and environmental practices is sought. Recent industry studies substantiate the "prevalence of managing the greening of supply chains responsibly and how it remains one of the most important sustainability challenges of organizations" (Lacy and Hayward, 2011; Lacy et al., 2012).

Nonetheless, GSCM practices are not easy to implement in India owing to their complex nature, need of a greater degree of coordination, resource requirements and lack of willingness on the part of organizations. Thereby it is realized that in order to successfully implement the GSCM practices in India, a strong will along with the right attitude on the part of employees and organization as a whole is required.

\section{Indian Automobile Industry: Present Scenario}

The Indian automobile industry has come a long way since its birth in the 1940's to become one of the largest in the world with an annual production of over twenty million vehicles. It has seen considerable growth in the last 20 years mainly due to economic liberalization including 100\% FDI in the sector. The automobile industry accounts for $22 \%$ of the country's manufacturing gross domestic product (GDP) (SIAM, 2015). Ingredients such as availability of large number of skilled workers, low production cost, faster design and development process and new emerging market status are stimulants causing global auto manufacturing companies to establish R\&D facilities in India. Some of these multinational companies outsource most functions regionally while retaining control on product development and strategic procurement (Auto SCM India 2006) A 
plethora of groups such as assemblers, multinational assemblers, Indian component suppliers, multi-national component suppliers, each with its own specific strengths and weaknesses form the automotive industry (Ray, S., 2012). India's automotive industry is the world's sixth largest producer of automobiles in terms of volume and value and has grown $14.4 \%$ in the last decade. The industry contributes $7 \%$ to India's GDP, $7-8 \%$ of the total employed population (about 13 million people), $4 \%$ of exports (AT Kearney 2013), \& SIAM India 39\% of FDI inflows (USD 5.5 billion between 2009 -13) it contributes $17 \%$ to total indirect taxes collected. Overall domestic sales are led by two-wheelers, (77.4\% of total sales in 2012-13) followed by passenger vehicles $(15.1 \%)$ and commercial vehicles (4.45\%) SIAM India - Society of Indian Automobile Manufacturers (SIAM), 2014. However, despite of earnings of 4 billion USD (including 1.8 billion USD of auto component sector) through exports, the automotive sector contributes only $2.37 \%$ of world production and is ranked very low at $26^{\text {th }}$ in the world auto export market with a share of $0.53 \%$. Nonetheless, Indian automotive industry is striving for global competitiveness and is taking noticeable steps in that direction; India has the best-in-class fuel economy rates (KPMG, 2006, \& Swaminathan, J.M., 2006). By 2050, the country is expected to top the world in car volumes with approximately 611 million vehicles on the nation's roads (Sarin, 2015). Realising the importance of the auto industry, which has grown-up in seven 'clusters' and its involvement to financial growth, the Indian government laid out the goals of the industry in two documents - 'Auto Policy 2002' and 'Auto Mission Plan 2006-16 (Automotive 2006). The Government has taken active steps to realize a target of USD 145 billion in output contributing to $10 \%$ of the GDP and providing further employment to 25 million people by 2016. The setting up of manufacturing facilities in India by large automakers like Hyundai, Ford, Toyota etc has also ensured rapid establishment and growth of an energetic auto component sector (Auto SCM India 2006). "Design, development and replication capabilities have increased significantly and global companies like Bosch, Goetze-Werke and Johnson Control have set up facilities in India" as brought out by Joshi, et al (2013). The multi-tiered auto component industry presently contributes significantly to the overall growth of the automobile Industry and major part of exports go to the Original Equipment Manufacturers and major suppliers and only $30 \%$ to global aftermarkets, which indicates towards the advancements in this sector (Automotive 2006). Automakers are increasingly looking towards so far untapped rural markets in India due to enhanced buying capacity. Moreover, indigenization of automotive manufacturing and its associated activities are likely to gather pace with intensification of 'Make in India' campaign.

The above circumstances indicate that the Indian automotive industry has prospects for considerable growth. This makes it vital for the industry to achieve competitive advantage through acceptance of global supply chain best practices. GSCM practices have become the focal point for the automotive industry as the general public has become more concerned about how organization deals with social and environmental issues and give back to society from which they takes out profit. The increasing criticism of the automobiles as the single largest source of pollution has put immense pressure on companies to upgrade not only the technology to increase the effectiveness and use better emission control devices but also to incorporate green measures in their supply chain networks (Shukla et al., 2009). Due to the growing concern of the environment issues, a leading group of companies in the automobile industry including Hyundai Motors, Toyota, and BMW have adopted "green" standards in their SCM. Saad and Patel (2006) argued that Indian automobile sector is not implementing the philosophy of supply chain in its true sense. Some of the problems with the Indian automobile sector may be classified as: large number of auto assemblers, low-technological capability, poor quality, lower reliability in terms of delivery, large number of players in automobile sectors, small capacity of autoancillary firms, lack of availability of components 
and lack of strong partnership among partners in the supply chain (Charan, 2012).

The paper is further structured as follows: Section 4 defines the Green Supply Chain practices in Indian Automobile Industry where as section 5 identifies various drivers of the GSCP as identified in the literature review which further described the role of stakeholders in GSCP. The section 6 classifies the stakeholders with the help of various studies done in this regard. Finally the section 8 concludes the work and gives the future research direction.

\section{Green Supply Chain Practices (GSCP) in Automobile Industry}

The Indian Automobile industry has witnessed many challenges during the past few years in terms of supply chain. Singh et al. (2004) observes that after liberalization, many global automobile manufacturers have established manufacturing bases or international purchase centers in India. This has intensified the competition among the automobile firms, motivating them to be innovative as to reduce costs, enhance quality, and improve level of their supply chains. In a study, Yu and Thomas (2011) suggested that as automobile manufacturing involves hundreds of parts from many suppliers; supply chain management becomes critical area in operations management of the industry and a vital factor for the success or endurance of the auto makers.

Though automobile parts manufacturing companies have initiated multiple dimensions of GSCM practices, as well as internal environmental management, green purchasing, green marketing and eco-design, producing environmentally robust engines is one key dimension that is used to establish their environmental image, and thus gain and keep competitiveness. With increased public consciousness, tightening of environmental norms and state investments in production and distribution of cleaner fuels, leading manufacturers in this competitive market have been forced to upgrade their engine technologies to be in compliance with environmental legislations. They have worked on improving the environmental by producing engines by lowering emissions, fuel consumption and noise, as well as high dynamic functions and dependability.

In the perspective of the Indian auto industry, Ravi and Shankar (2005) have identified five strong barriers namely: lack of awareness of overturn logistics, lack of commitment by the top management, problems with product quality, lack of tactical preparation and financial constraints which hinder the successful execution of GSCM practices. Nevertheless, these aspects are not unique to Indian industry alone. With recessionary threats to prevailing market conditions, sluggish auto sales, unstable petroleum industry, and the blurring future for new technologies adversely impacting the operational competence, supply chain management of the auto industry becomes one of the important elements for the survival or success of the very industry (Webster, 2006).

Therefore, due to the supply chain management's significant role in the auto industry, there is a need to think strategically and critically regarding the strengths and weakness of the field, examine closely the opportunities and pressure in the global environment and offer suggestions to make the most of benefits for all stakeholders and maintain the sustainability of the auto industry ( $\mathrm{Yu} \mathrm{Xia}$ and Thomas Li-Ping Tang, 2011). Moreover as is evident that relatively the auto industry is fit to be considered a mature industry overall because its products, process architectures, and values are steady; however, due to global warming, the energy for the auto industry in terms of source as well as storage and supply of green and renewable energy takes the center stage and becomes a prevailing challenge in the near future (Tang, 2010). As the green energy today is in the undeveloped stage of the life cycle, therefore, the auto industry straddles both grown-up and young industries and requires a new, innovative, and imaginative design for the 
supply chain management (Yu and Thomas, 2011).

Vachon and Klassen (2006) mentioned that researchers still struggle to give a widely accepted definition of GSCP due to lack of consensus in what all activities should be included in GSCP and also whether GSCP should include externally oriented practices only. Whereas in contrast, regarding the scope of the analysis conducted on GSCP by Zhu et al. (2008b) and Sarkis et al. (2010), it is argued that the scope of GSCP is a broader area. . Environmental management systems and investment recovery may be considered as internal practices; where as green purchasing and co-operation with customers for green packaging may be classified as external practices.

Zhu et al. (2007a) and Gonzalez et al. (2008) tested
GSCP in the automobile industry, while Zhu and Sarkis (2004) and Zhu et al. (2007b) conducted the study across several sectors. According to Tate et al. (2010), the emphasis on various activities may vary depending on type of industry as well as size and geographic location. Zhang et al. (1997), Zhu and Deshmukh (2003) and Diwekar and Shastri (2010) focused on green design as an important practice while, Wong et al. 2005 and Kim et al. (2007) felt that it was repairable inventory and for (Guide 2000), it is production planning and control for remanufacturing. The focus was on green manufacturing and product recovery for (Guide et al. Sarkis 2004 and Zhu et al. 2008b). GSCP is finally classified by various authors into five main categories that are: internal environmental management, green purchasing, customer cooperation, investment recovery, and eco-design.

Table-1

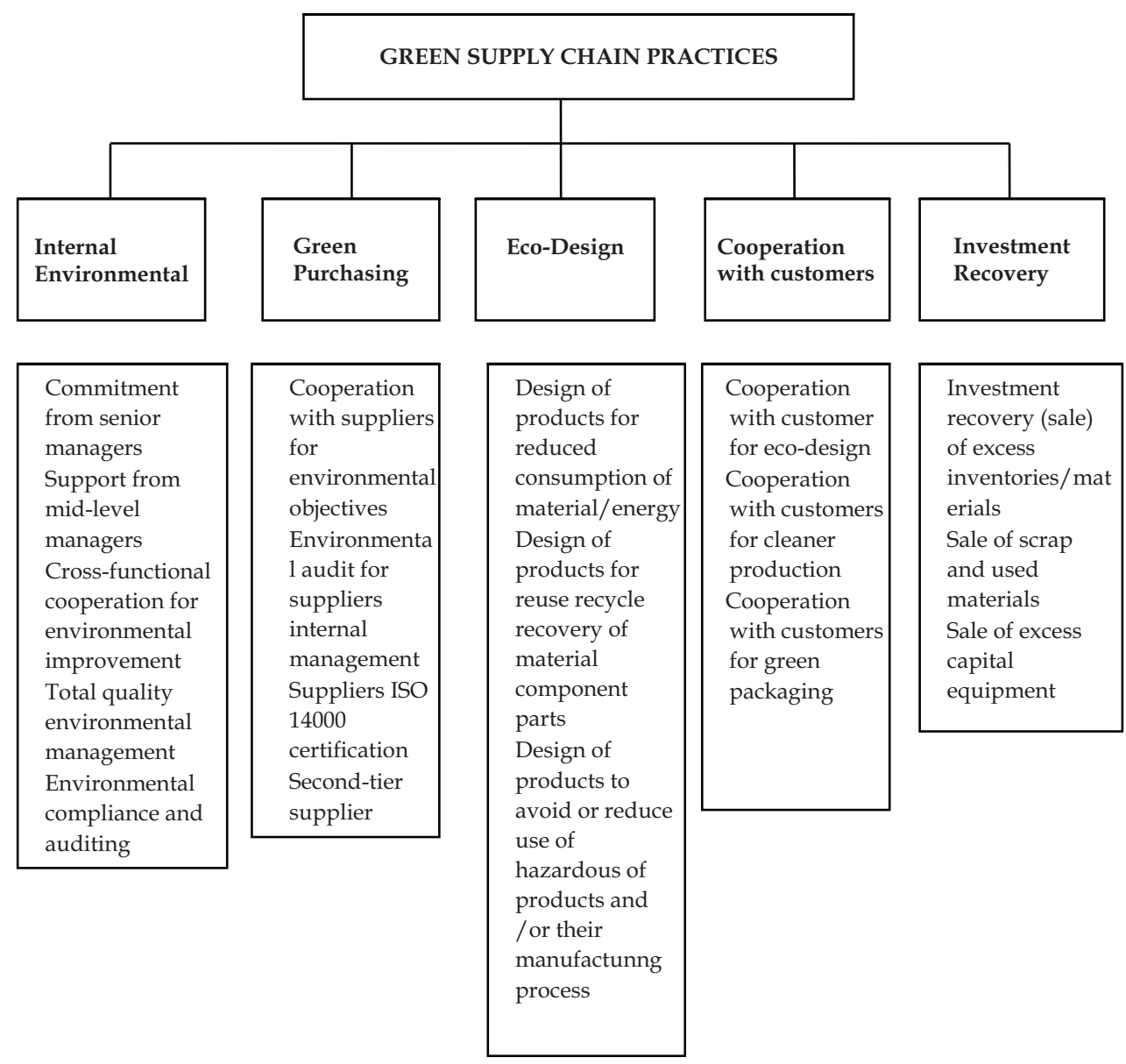




\section{Internal Environment Management}

Internal environmental management is the practice of developing green supply chain management as a strategic organizational necessity through commitment and support of senior and mid-level managers (Zhu et al., 2008a). Besides the government providing incentives to green manufacturers, private insurance companies are also contributing by offering better rates to manufacturing companies that are taking steps to go green.

\section{Green Purchasing}

Environmental purchasing or Green Purchasing is process of collection and attainment of product and services which minimize negative impact over the life cycle of manufacturing, transportation, use and recycling. Green purchasing focuses on cooperating with suppliers for the reason of rising products that are environmentally sustainable $\mathrm{Zhu}$ et al., (2008a); Carter and Carter, (1998). Essentially, it is the act of choosing products or services that have a less undesirable effect on human health and the environment, when compared with challenging products or services that serve the same intention. Use of energy efficient products, limiting the use of toxic elements and reducing waste are some of the criteria for environmentally preferable purchasing. The purchasing function of an organization has to play a greater role in terms of procuring risk-free as well as pollution-free materials and components, which finally go into setting the environmental characteristics of finished products. However, while there are environmental regulations, enabling legislations as well as the increasing demand of environmental friendly goods from buyers, presently there is a limited market for ecofriendly products. Nevertheless, with combined efforts of governments, industries and civil society organizations, there are definite signs that market for eco products would grow in a big way.

\section{Cooperation with Customers}

Cooperation with customers requires functioning with them to design cleaner production processes in order to produce environmentally sustainable products with green packaging (Zhu et al., 2008a). This involves obtaining active feedback and inputs from the consumer right from the innovation stage to production and customer's user satisfaction feedback. This is applicable to industrial as well as consumer goods.

\section{Eco-design}

Eco-design requires that manufacturers design products that minimize expenditure of resources and power, that assist the reuse, recycle, and recovery of element equipment and parts, and that avoid or reduce the use of dangerous products within the manufacturing process (Zhu et al., 2008a). This approach involves conserving the natural resources, reducing the toxicity of a product, extending the life of a product, extending the life of the material used and improving the selection of materials and processes.

\section{Investment Recovery}

Investment recovery requires the sale of excess inventories, scrap and used materials and excess capital equipment (Zhu et al., 2008a). Investment recovery which may includes sale of excess inventories, scrap, used materials and extra or no longer useful objects is quite effective way of cost saving and increasing revenue, thus adding to net asset value to the company. Such steps not only facilitate short term cash flow, reduced inventory clutter, improved storage space, cutting in operational costs, but also enhance company's reputation as flag bearer of environmental concerns.

\section{Drivers of Green Supply Chain Practices: An exploration}

The increased levels of energy and material 
consumption caused by hastened economic growth contribute to issues related to environment and resource reduction problems. Hence, maintaining balance between economic and environmental performance has assumed increased significance for organizations facing competitive, regulatory, and community pressures; that is to sustain an all encompassing relationship of profit, people and planet (Willard, 2009). Addressing this sustained relationship can not be limited to a business ventures' own internal operations; instead, its supply chain is an important network where operational competitiveness, environmental management, and social behavior intersect (Vachon \& Klassen, 2006).

Several studies on GSCM have determined a broad range of factors that combine in to environmental management initiatives and practices. Thereby there have been various studies which have found the important drivers of Green Supply Chain Practices (GSCP) which have been tabulated as under:

Table-2

\begin{tabular}{|c|c|c|c|c|}
\hline Year & Year Title/Author & Findings & Variables & Country \\
\hline 2015 & $\begin{array}{l}\text { Thoo Ai China, et al.; } \\
\text { Green Supply Chain Management, } \\
\text { Environmental Collaboration and } \\
\text { Sustainability Performance }\end{array}$ & $\begin{array}{l}\text { GSCM and sustainability performance is a concept } \\
\text { which is difficult to separate from SCM concept -It } \\
\text { is how firms can develop value creating linkages } \\
\text { with sustainability to achieve desired outcomes. }\end{array}$ & $\begin{array}{l}\text { Economic Performance } \\
\text { Environmental } \\
\text { Performance - Social } \\
\text { Performance }\end{array}$ & Malaysia \\
\hline 2011 & $\begin{array}{l}\text { Chiou, T.Y. et al.; } \\
\text { The Influence of Greening the } \\
\text { Suppliers and Green Innovation on } \\
\text { Environmental Performance and } \\
\text { Competitive Advantage in Taiwan }\end{array}$ & $\begin{array}{l}\text { Greening the suppliers leads to green innovation } \\
\text { and competitive advantage. } \\
\text { - The finding also support that the intervening } \\
\text { variables of green innovation contribute to } \\
\text { competitive advantage. } \\
\text { - Taiwanese companies have started to } \\
\text { implement actions toward greening their suppliers } \\
\text { and developing greener }\end{array}$ & $\begin{array}{l}\text { Green innovation } \\
\text { (Product innovation, } \\
\text { Process innovation, } \\
\text { Managerial Innovation) } \\
\text { - Environmental } \\
\text { performance } \\
\text { - Competitive advantage }\end{array}$ & Taiwan \\
\hline 2011 & $\begin{array}{l}\text { Yan Li; } \\
\text { Research on the Performance } \\
\text { Measurement of Green Supply Chain } \\
\text { Management in China }\end{array}$ & $\begin{array}{l}\text { They have tried to implement a variety of GSCM } \\
\text { practices to improve their environmental } \\
\text { performance in export -Internal environmental } \\
\text { management, (support from mid level and top } \\
\text { level anagers) }\end{array}$ & $\begin{array}{l}\text { Eco-design level; green } \\
\text { purchasing level; green } \\
\text { manufacturing capacity, } \\
\text { green marketing and } \\
\text { recycling of products }\end{array}$ & China \\
\hline 2014 & $\begin{array}{l}\text { Mohd. Asif Gandhi ESanjay Sharma } \\
\text { A Review of Research Methodologies } \\
\text { Linking Green Supply Chain Practices } \\
\text { and Green Supply Chain Performance }\end{array}$ & $\begin{array}{l}\text { An empirical study on linking green supply chain } \\
\text { practices and green supply chain performance }\end{array}$ & Only Review Literature & India \\
\hline 2014 & $\begin{array}{l}\text { Karthik Kudroli; } \\
\text { Green supply chain management and } \\
\text { environmental sustainability - a } \\
\text { comparative study on global and } \\
\text { Indian perspective }\end{array}$ & $\begin{array}{l}\text { Indian Firms are feeling pressurized to follow } \\
\text { Indian and International Regulations }\end{array}$ & $\begin{array}{l}\text { Strategy Logistics } \\
\text { Environment }\end{array}$ & India \\
\hline 2005 & $\begin{array}{l}\text { Aref A et al.; } \\
\text { Performance measurement for green } \\
\text { supply chain management }\end{array}$ & $\begin{array}{l}\text { Implementation and operation of GSCM. Selected } \\
\text { measures and metrics must be implemented } \\
\text { within a framework much like the strategic } \\
\text { planning model }\end{array}$ & $\begin{array}{l}\text { External Pressure Internal } \\
\text { Control }\end{array}$ & US \\
\hline 2007 & $\begin{array}{l}\text { Simpson et al.; } \\
\text { Greening the automotive supply } \\
\text { chain: a Relationship perspective }\end{array}$ & $\begin{array}{l}\text { Traditional operations theory on inter } \\
\text { organizational Performance improvement is just } \\
\text { as relevant to the use of environmental }\end{array}$ & $\begin{array}{l}\text { Customer environmental } \\
\text { Performance } \\
\text { requirements } \\
\text { - Supplier environmental } \\
\text { commitment }\end{array}$ & $\begin{array}{l}\text { Australia; } \\
\text { Automoti } \\
\text { ve } \\
\text { Industry }\end{array}$ \\
\hline 2007 & $\begin{array}{l}\text { Chien, M. K. and Shih, L. H.; An } \\
\text { empirical study of the implementation } \\
\text { of green supply chain management } \\
\text { practices in the electrical and } \\
\text { electronic industry and their relation } \\
\text { to organizational performances }\end{array}$ & $\begin{array}{l}\text { Original equipment manufacturing and designing } \\
\text { they adopted green procurement and green } \\
\text { manufacturing practices in response to the current } \\
\text { trend of international green issues and have } \\
\text { caused positive environmental and economic } \\
\text { performances for the companies }\end{array}$ & $\begin{array}{l}\text { Environmental } \\
\text { regulations, External } \\
\text { stakeholders, GSCM } \\
\text { practices, Environmental } \\
\text { performance, Financial } \\
\text { performance }\end{array}$ & $\begin{array}{l}\text { Taiwan; } \\
\text { Electrical } \\
\text { and } \\
\text { Electronic } \\
\text { Industry }\end{array}$ \\
\hline
\end{tabular}




\begin{tabular}{|l|l|l|l|l|}
\hline 2014 & $\begin{array}{l}\text { Sharma } \text { M.; } \\
\text { The role of employees'_engagement in } \\
\text { the adoption of green supply chain } \\
\text { practices as moderated by } \\
\text { environment attitude: }\end{array}$ & $\begin{array}{l}\text { The results indicate that the pressure environment } \\
\text { attitude has some moderating effect in improving } \\
\text { GSCM practices. In the discussion of the results, } \\
\text { the focus is on the reasons why certain significant } \\
\text { characteristics exist. The study suggests that future } \\
\text { research can focus on supply chain performance } \\
\text { which may be classified as environmental and } \\
\text { economic performance measures of GSCM } \\
\text { practices }\end{array}$ & $\begin{array}{l}\text { Environmental attitude } \\
\text { Automobi } \\
\text { le } \\
\text { Industry }\end{array}$ \\
\hline 2010 & $\begin{array}{l}\text { Wilson o. omonge; } \\
\text { Green supply chain management } \\
\text { practices and competitiveness of }\end{array}$ & $\begin{array}{l}\text { The potential benefits for integrating green supply } \\
\text { chains in the operations of a firm are compelling } \\
\text { to any organization in the present day competitive } \\
\text { environment is possible with the consumers } \\
\text { having sufficient knowledge about it and it is } \\
\text { recommended that public awareness of product }\end{array}$ & $\begin{array}{l}\text { Competitiveness Cost, } \\
\text { Profitability, Pricing, } \\
\text { base, Customer loyalty, } \\
\text { Share value, Dividend }\end{array}$ & $\begin{array}{l}\text { Kenya, } \\
\text { Commerci } \\
\text { al Banks }\end{array}$ \\
\hline
\end{tabular}

\section{Stakeholders' Intervention in Green Supply Chain Practices}

Role of stakeholders takes prominence in green supply chain management with organizational value chain of customers supplies and multilevel distributors. It leads to increased Economic Value Added (EVA) achieved through a higher strategic fit across the entire set of activities in the value chain (Subir Sen,2009). Firms at different stages of development in regards to their approach to GSCM practices will very likely engage in different practices even though this may not essentially mean that firms at complex stages would connect in a bigger number of practices, as opposed to perhaps focusing on a less number of chosen practices that better serve their objectives. Matten and Moon (2008) discussed these factors in terms of institutional theory, and Benn et al. (2006) discussed them in terms of stakeholder theory, both articles arguing that a composite mix of regulations, governance and stakeholder forces influenced the rate of a firm's progression towards more green practices. Some of the supply chain practices of firms studied have been subjected to strong examination over the last 10 years. The stakeholder concept was articulated in a study in the 1960s at the Stanford Research Institute (Freeman, 2010; Preble, 2005). It is likely that these external forces have inclined the industries' current understandings they have incorporated in Green supply chain management practices. Such steps can be motivated by the organization's stakeholders' requests and swayed by organization's aim to have complete compliance with environmental regulations, which may potentially provide opportunities to gain market advantage.

\section{The classification of Stakeholders: The theoretical model}

The term "stakeholder" identified the wider hypothesis that others beyond shareholders affected, and in turn, were affected by a firm's activities (Preble, 2005). The dynamic nature of modern business relationships support the idea that uncertain and evolving business environments call for ways to scan for emerging issues so that managers can develop appropriate responses; observation of stakeholder requests help interpret these external changes (Preble, 2005). Some changes include the emergence of consumer and environmental activist groups, an increase in government regulation and monitoring activities, market globalization and competition, an intensification of media attention and hostility, and the relative loss of confidence in business (Freeman, 1984). Stakeholder theoretical models support a view of aggregate and complex supply chain relationships. A stakeholder map of an organization may include various groups with a investment or interest in the success and activities of the firm such as owners, suppliers, competitors, employees, customers, community, government, political groups and others (Freeman, 2010). Freeman (2010) further emphasized that stakeholder necessities are input motivators for tactical actions taken by firm managers, including ethical and financial activities. Russo and Perrini (2010) pointed out that by 
extension, it is public awareness tempered by media exposure, social and cultural changes will guide socially responsible actions. The widening corporate functions brought about the realization that their activities had the potential to impact the general well being and interests of the society. A firm's survival and success is dependent on its ability to secure monetary benefits and satisfaction for its primary stakeholders. Withdrawal of support by any of the primary stakeholder affects the firm's operation adversely (Clarkson, 1995). Hence, therein lies the need to acknowledge and integrate such key social issues which significantly affect the primary stakeholders, with organizational policies and practices. For each type of stakeholder, there should be dyadic ties between the firm and the stakeholder group (Rowley, 1997). Stakeholder pressure refers to the level of accountability an organization perceives for the actions and decisions it takes pertaining to product design, sourcing, production, or distribution to stakeholders (Parmigiani et al. 2011). The differing expectations_across different stakeholder groups, makes it difficult for organizations to react to all of them. In extreme situations, stakeholder claims may even present contradictory demands to organizations (Gavetti et al. 2005). Consequently, some organizations have evolved stakeholder management strategies that evaluate stakeholder claims in terms of their munificence, salience and urgency (Mitchell et al.1997). Mishra and Suar (2010) have referred to some of the global standards, and national regulations and guidelines in India to examine issues on corporate responsibility with respect to six primary stakeholder groups: employees, customers, investors, community, natural environment and suppliers. Thereby the stakeholders have been divided into categories: internal stakeholders and external holders whereby the primary stakeholders may consist of: suppliers, investors and customers and secondary stakeholders may include Government regulations and hence their individual impact may be studied on GSCM Shafiq et.al.(2014) gave the following four major stakeholders in efforts towards meeting expectations of organization which can be taken as a scale to classify the stakeholders in Indian Automobile Industry.

Table-3

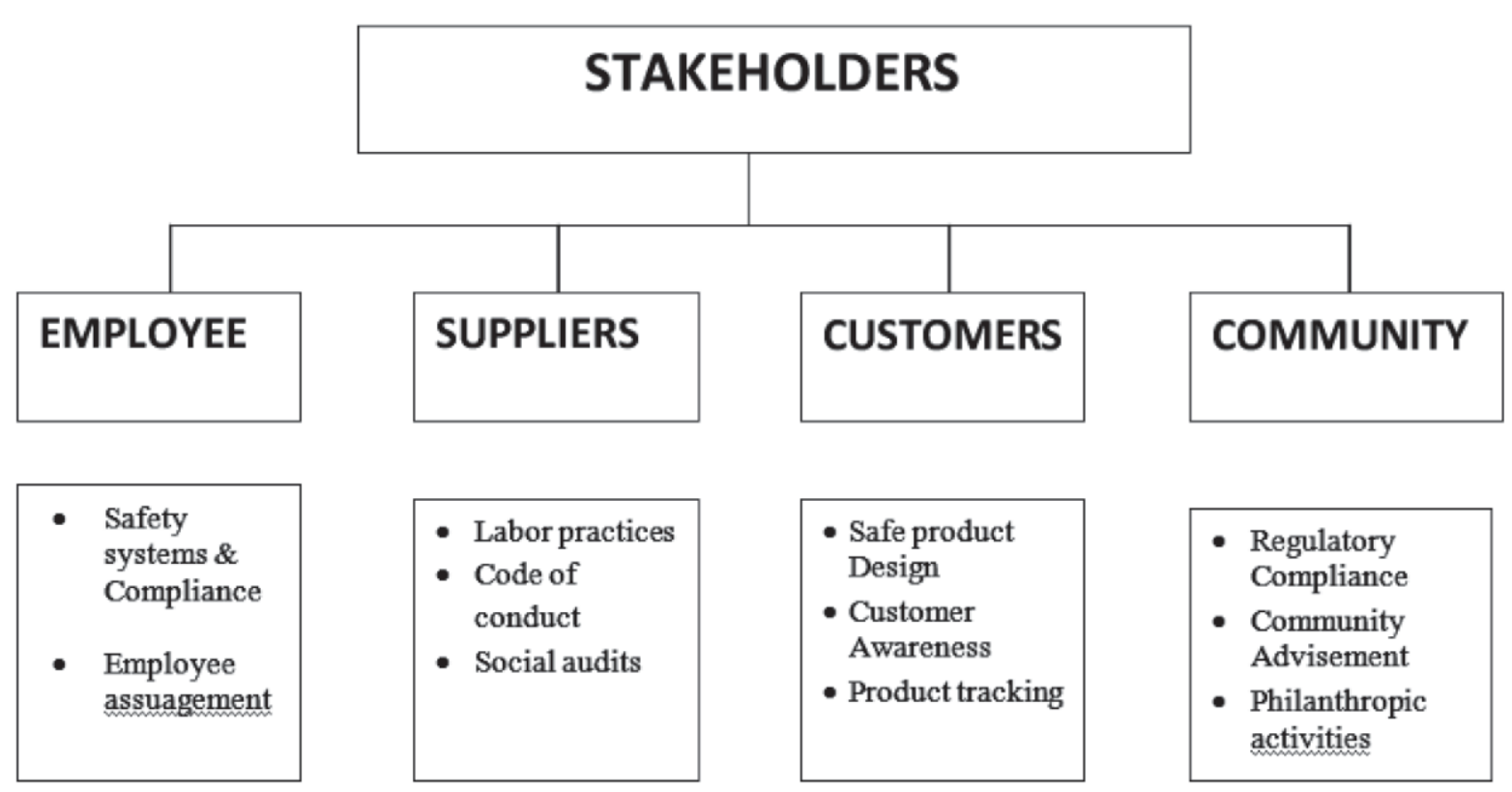




\section{Employees as Stakeholders}

Most researchers refer to employees as main internal stakeholders and classify their concerns under the three main categories of workplace issues, safety and health issues and discrimination and affirmative action issues (Carroll and Buchholtz, 2008). While Clarkson (1995) outlines a list of internal stakeholder concerns that include human resource-related concerns, such as compensation and benefits, career planning, leaves of absence, and termination and layoff issues. The management has significant influence in fostering a safe environment, which is a component of the organizational culture encompassing the individuals, jobs, and the organizational measures affecting employees' health and safety. Employees' performance is constructively influenced by a safe working environment whose maintenance has become an important parameter of an organisation's social practices. Such internally focused practices are those influences on Green Supply Chain Management which steer implementation and adoption of GSCM in manufacturing industries. A firm with a good social and ethical reputation is a more attractive employer compared to firms with an average or poor social and ethical record (Turban \& Greening, 1997). Organisational emphasis on promotion and maintenance of the physical, mental and social wellbeing of workers facilitates employee motivation which is described as an employee's basic enthusiasm about work and incentives given to accomplish work. Incentives may range from satisfying the employee's requirements and prospect from work, good working conditions acknowledging and rewarding their work including monetary rewards. Apropos social identity theory which states that self-concept of an employee is influenced by membership in an organization (Ashforth \& Mael, 1989). The benefits are visible across the board from existing employees to attracting new employees who exhibit enhanced motivation, greater willingness to engage in cooperative behavior, and remain affiliated to a firm that is perceived as a moral and an ethical employer (Dutton,et.al. 1994). Therefore, focusing on improving employee skills yields longlasting benefits for an organization.

\section{Suppliers as Stakeholders}

Integration and cooperation in supply chains facilitate more effective management of environmental issues and therein the suppliers play a very important role. Whilst suppliers may not be the direct guides, their contribution in GSCM lies more in the manner of generating and providing valuable ideas in the implementation of environmental projects. Notwithstanding the indirect role of suppliers in guiding policies of an enterprise, they are considered key stakeholders in strategy literature (Swanson, 1995), and have an immense responsibility in ensuring adherence to ethical and environmental standards. Any such violation on their part will have wide spread ramifications for a firm's social image and reputation and that is why firms need to evolve exhaustive and extensive procurement practices to minimize the risk of any such potential damage coming from supplier. Dyadic studies of buyer-supplier relationships have strengthened the view that long-term commitment, ethical leadership in both buying and supplying organizations, and the level of coordination among the two partners are related to better ethical and social performance of both parties (Carter, 2000a, b; Hill, Eckerd, Wilson, \& Greer, 2009). The trend of moving production to overseas suppliers has resulted in additional responsibility on the supply chain function of firms to not only diligently monitor their suppliers for product-related issues but to also manage their social conduct. Therefore, as firms are more likely to engage with multi tiered supply networks in today's globalised world, it is imperative that they work out a strategy for development and implementation of a code of conduct and enforce its reinforcement through rigorous social audits. Emmelhainz and Adams (1999) mentioned the three tasks that a buying organization must perform to improve the social conduct of their suppliers as the development of a formal code of conduct document, which serves as a guideline for suppliers to ensure 
social adherence, the development of a social auditing system for suppliers, which includes plant inspections and on-site visits and the enforcement of such policies by devising contractual obligations against social breach from either the supplier or the buying firm.

\section{Customers as Stakeholders}

The most important stakeholders that help establish a firm's reputation and identification are its customers whose satisfaction is the key to a company's success. However, viewing customers as a revenue generator apart from being Stakeholder is a delicate balance between two different and rather competing issues. The customers' examination form a stake holder perspective yields deeper insight into their influence in shaping the ethical conduct of a firm. Such exploration gives a few advantages to the subject firms. At first mutual expectations grow between the Customer and the form. Enhanced trust and faith leads to fair dealing between the two. Above all it develops long term and deeper customer loyalty. However the companies need to adopt more customer friendly practices such as emphasis on consumer safety during product use, transparency of consumer product information including the procurement of raw material, an ambiguity in product's supply Chain product quality, truthful promotions and product recall to tap such benefits. Here customer awareness plays an extremely important role. Customer's demand for environment friendly products and awareness compels firms towards, adoption of GSCM in manufacturing industries. Customer awareness is that factor of Green Supply Chain Management which emanates from the understanding and knowledge that a buyer should have of his rights as a customer and is very important since it permits him not only to get the most from what he buys, but also influence and directly impact the product design and production process by demanding eco friendly products that address recycling, sustainable production, and reduction of energy consumption and transport. Consumer awareness is making existing and potential customers knowledgeable about product's services and is facilitating consumers in arriving at more informed buying decisions.

\section{Community as Stakeholder}

A community can be termed as a social unit that shares common values or that is situated in a given geographical area. Thus, the three ingredients of a community are: Interaction, identity and geography. A shared concern for the welfare of the community can strengthen a mutually beneficial relationship between a firm and the community it operates in. Whereas the CSP increase attractiveness of an employer in the community (Backhaus, et.al. 2002). This causal relationship between the business enterprise and the community and its environment that the firm operates in and their mutual interaction may be a manifestation of different factors such as society or public pressure, environmental concerns \& legislature, social \& environmental responsibility and global climate \& ecological concerns.

\section{Conclusion and future research direction}

India has a long way to adopt new technologies and new practices which are adopted globally in automotive sector. Present need is to take effective measures in modifying the current Green Supply Chain Management Practices which can be done by including the stakeholders in the implementation of such practices in the organization. On the basis of the above literature, it is understood that although there have been studies to understand the relationship between GSCP and Stakeholders but there has not been much work which may talk about how stakeholders may play an important role in the adoption of GSCP as a whole specifically in automobile industry. Thereby, there is a need to develop a conceptual model which may discuss the role of stakeholders in implementing the GSCP and further enhancing the positive relationship. Moreover due to the Green supply chain management's critical role in the automobile industry, there is a need to focus the study in this 
industry. The literature review done in this context is only suggestive of the link between stakeholders' pressure on green supply chain practices. The role of stakeholders may be observed in many positions vis a vis the green supply chain practices as independent variable, moderating or mediating variable and should be tested empirically with the survey data.

\section{REFERENCES}

1) Andriof, J., Waddock, S., Husted, B. \& Rahman, S. 2002. Unfolding Stakeholder Thinking: Theory, Responsibility, and Engagement. Sheffield UK: Greenleaf Publishing.

2) ACMA, 2013. Presentation on "Auto Component Industry in India: Growing Capabilities and Strengths", retrieved from www.acma.in.

3) AT Kearney 2013, "Building world class supply chain in India", Conference on Auto Supply Chain Management, retrieved from www.atkearney.com.

4) Auto SCM India 2006, Chennai, “Background note on Supply Chain management in Automotive Industry", retrieved from https://www.scribd.com/.../Supply-ChainManagement-in-Automobile-Industry

5) Automotive 2006 "Automotive Mission Plan 2006-2016 - A Mission for Development of Indian Automotive Industry", Ministry of Heavy Industries \& Public Enterprises, Government of India, retrieved from http:/ / dhi.nic.in

6) Ashforth, Blake E. and Fred Mael, 1989 Social Identity Theory and the Organization. The Academy of Management Review,14, (1), 20-39.

7) Backhaus, K. B., Stone, B.A., \& Heiner, K. 2002. Exploring the relationship between corporate social performance and employer attractiveness. Business and Society, 41(3), 292-318.

8) Benn, S., Dunphy, D., \& Griffiths, A. 2006. Enabling change for corporate sustainability: An integrated perspective. Australasian Journal of Environmental Management, 13(3), 156-165.

9) Carter, R.C. and Carter, J.R. 1998. Interorganizational determinants of environmental purchasing: initial evidence from the consumer products industry. Decision. Sciences, 29, 28-38.

10) Carter, C. R., \& Rogers, D. S. 2008. A framework of sustainable supply chain management: Moving toward new theory. International Journal of Physical Distribution and Logistics Management, 38 (5), 360-387.

11) Caroll \& Buchholtz 2008. Business and Society: Ethics and Stakeholder Management Business \& Economics - 992 pages

12) Charan, P. 2012. Supply chain performance issue in an automobile company: A SAP-LAP analysis. Measuring Business Excellence, 16(1), 67-86.

13) Christopher, M. 1998. Logistics and Supply Chain Management - Strategies for reducing cost and improving service, 2nd ed., London.

14) Clarkson, M.E. 1995. A stakeholder framework for analyzing and evaluating for corporate social performance. Academy of Management Review, 20(1), 92-117.

15) Crane, A. \& Matten, D. 2004. Business ethics: a European perspective. Oxford: Oxford University Press.

16) Dargush \& Ward 2010. Understanding corporate social responsibility with the integration of supply chain management in outdoor apparel manufacturers in North America and Australia. International Journal of Business and Management Science, 3(1), 93-105.

17) De Brito, Carbone and Blanquart. 2008. Towards a sustainable fashion retail supply chain in Europe: organization and performance. International Journal of Production Economics,114, (2), 534-53.

18) Diwekar, U.M., \& Shastri, Y.M. 2010. Green process design, green energy, and sustainability: A systems analysis perspective. Computers $\mathcal{E}$ Chemical Engineering, 34(9), 1348-1355.

19) Dutton et al. 1994. Organizational Images and Member Identification.Administrative Science Quarterly. 39, 239-263.

20) ElTayeb, T.K., Zailani, S., \& Jayaraman, K. 2010. The examination on the drivers for green purchasing adoption among EMS 14001 certified companies in Malaysia. Journal of Manufacturing 
Technology Management, 21(2), 206-225.

21) Eltantawy R, Reham A., Giunipero Larry \& Fox Gavin L. 2009. A Strategic Skill Based Model of Supplier Integration and its Effect on Supply Management Performance, Industrial Marketing Management, (38) 925-236.

22) Emmelhainz, M. A. and R. J. Adams. 1999. The Apparel Industry Response to 'Sweetshop' Concerns: A Review and Analysis of Codes of Conduct", Journal of Supply Chain Management. 35(3), 51-57.

23) Freeman (1984). Strategic Management: A Stakeholder Approach (Pitman, Boston).

24) Freeman, 2010. Stakeholder theory: The state of the art. Cambridge: Cambridge University Press.

25) Fisher, M.L.1997. What is the right supply chain for your product?, Harvard Business Review, March-April,105-116.

26) Gavetti, G., Levinthal, D. A., \& Rivkin, J. W. 2005. Strategy making in novel and complex worlds: The power of analogy. Strategic Management Journal, 26(8), 691-712.

27) Gonzalez, P., Sarkis, J., and Adenso-Diaz, B. 2008. Environmental management system certification and its influence on corporate practices: evidence from the automotive industry. International Journal of Operations and Production Management 28 (11), 1021-1041.

28) Guide V.D.R., Jr. 2000. Production planning and Control for remanufacturing: Industry Practice and research needs, Journal of Operations Management, (18), 467-483.

29) Guide Jr.VDR .1996. Scheduling using drumbuffer-rope in a remanufacturing environment. International Journal of Production Research (34), 1081-1091.

30) Gungor, A., \& Gupta, S.M. 1998. Disassembly sequence planning for products with defective parts in product recovery. Computers $\mathcal{E}$ Industrial Engineering, (35), 161-164.

31) Hanifan, G., Sharma, A., Mehta, P. 2012. Why a sustainable supply chain is good business, Accenture, Outlook (3), 1-6.

32) Hoejmose and Adrien-Kirby. 2012. Socially and environmentally responsible procurement:a literature review and future research agenda of a managerial issue in the $21^{\text {st }}$ century. Journal of Purchasing and Supply Management, 18 (4), 232242.

33) Joshi, D., Nepal, B., Rathore,A.P.S. \& Sharma,D. 2013. On supply chain competitiveness of Indian automotive component manufacturing industry, International Journal of Production Economics, 143,151-161.

34) Kapoor, V. \& Ellinger, A.E. 2004. Transforming supply chain operations in response to economic reform: the case of a motorcycle manufactrer in India. Supply Chain Management: An International Journal, 9(1), 16-22.

35) Kim, J.S., Kim, T.Y., \& Hur, S. 2007. An algorithm for repairable item inventory system with depot spares and general repair time distribution. Applied Mathematical Modelling, (31), 795-804.

36) Kleindorfer, P.R., Singhal, K., \& Wassenhove, L.N. 2005. Sustainable operations management. Production and Operations Management. 14(4), 482492.

37) KPMG. 2006. Indian Automotive Supply ChainA Discussion paper, retrieved from www.in.kpmg.com India. http:// dhi.nic.in.

38) Lacy and Hayward. 2011. A New Era of Sustainability in Emerging Markets? Insights from a Global CEO Study by the United Nations Global Compact and Accenture. Corporate Governance, 11(4), 348-357.

39) Lacy, P., Haines, A. and Hayward, R. 2012. Developing strategies and leaders to succeed in a new era of sustainability: findings and insights from the United Nations Global CompactAccenture CEO Study, Journal of Management Development, 31(4), 346-357.

40) Lee, K. and Kim, J. 2009. Current status of CSR in the realm of supply management: the case of the Korean electronics industry. Supply Chain Management: An International Journal, 14(2), 138148.

41) Maignan, I., and Ferrell, O.C. 2001. Corporate citizenship as a marketing instrument Concepts, evidence, and research directions. 
European Journal of Marketing. 35 (3/4), 457-484.

42) Matten, D. and Moon, J. 2008. 'Implicit' and 'Explicit' CSR: A conceptual framework for a comparative understanding of corporate social responsibility'. Academy of Management Review, 33 (2), 404-424.

43) McWilliams, A. and Siegel, D. 2001. Corporate social responsibility: A theory of the firm perspective. Academy of Management Review, (26), 117-127.

44) Mishra, and Suar. 2010. Does Corporate Social Responsibility Influence Firm Performance of Indian Companies?. Jouirnal of Business Ethics (95), 571- 601.

45) Mitchell et al. 1997. Toward a Theory of Stakeholder Identification and Salience: Defining the Principle of Who and What Really Counts. The Academy of Management Review 22(4), 853-886

46) Moore, S. and Manring, S. 2009. Srategy development in small and medium sized enterprises for sustainability and increased value creation. Journal of Cleaner Production, 17(2), 276282.

47) Nwe, E.S., Adhitya, A., Halim I. \& Srinivasan, R. 2010. Green supply chain design and operation by integrating LCA and dynamic simulation. In Pierucci, S. \& Ferraris,G.B. (Eds). 20 ${ }^{\text {th }}$ European Symposiumon Computer Aided Process Engineering-ESCAPE20 ( $p p$. 1-6). Elsevier B.V.

48) Parmigiani, A., Klassen, R. D., \& Russo, M. V. 2011. Efficiency meets accountability: Performance implications of supply chain configuration, control, and capabilities, Journal of Operations Management, 29(3), 212-223.

49) Patel, T. 2006. Making Sense of Diversity of Ethical Strategies in Businesses: A Focus on the Indian Context. CRR Conference, Trinity College, Dublin.

50) Preble, J. F. 2005. Toward a comprehensive model of stakeholder management. Business and Society Review, 110(4), 407-431.

51) Ray, S. 2012. Economic Performance of Indian Automobile Industry : An Econometric Appraisal, Business Intelligence Journal, Vol. 5,(1).

52) Ravi, V., \& Shankar, R. 2005. Analysis of interactions among the barriers of reverse logistics. Technological Forecasting \& Social Change, 72, 1011-1029.

53) Rowley, T.J. 1997. Moving beyond dyadic ties: a network theory of stakeholder influences, Academy of Management Review, 22 (4), 887-910.

54) Russo, A., \& Perrini, F. 2010. Investigating stakeholder theory and social capital: CSR in large firms and SMEs. Journal of Business Ethics, (91), 207-221.

55) Sahay, B.S., Cavale, V., \& Mohan, R. 2003. The Indian supply chain architecture. Supply Chain Management: An International Journal, 8(2), 93-106.

56) Sarin. S .2015. In Business Marketing: Concepts and Cases, Mcgraw Hill Education publishers, (pp. 73)

57) Sarkis, J., Gonzalez-Torre, P., \& Adenso-Diaz, B. 2010. Stakeholder pressure and the adoption of environmental practices: The mediating effect of training. Journal of Operations Management, 28(2), 163-176.

58) Sarkis, J. 2012. A boundaries and flows perspective of green supply chain management, Supply Chain Management: An International Journal, 17 (2), 202-216.

59) Seuring, S. and Muller, M. 2008. From a literature review to a conceptual framework for sustainable supply chain management. Journal of Cleaner Production, 16(8), 1699-1710.

60) Shukla, A.C., Deshmukh, S.G., \& Kanda, A. 2009. Environmentally responsive supply chains: Learnings from the Indian auto sector. Journal of Advances in Management Research, 6(2), 154-171.

61) Seuring, S. and Muller, M. 2008. From a literature review to a conceptual framework for sustainable supply chain management. Journal of Cleaner Production, 16(8), 1699-1710.

62) Singh, R.K., Garg, S.K., \& Deshmukh, S.G. 2004. Competitiveness of small and medium enterprises: case of an Indian auto component manufacturing organization. IIMB Management Review, 16(4), 94-102.

63) SIAM India - Society of Indian Automobile Manufacturers (SIAM), retrieved from www.siamindia.com. Jan 14. Society of Indian 
Automobile Manufacturers (SIAM), Union Budget 2014-15

64) Soni,G.and Kodali,R. 2011. The strategic fit between Competitive strategy and supply chain strategy in India manufacturing: an empirical approach, Measuring Business Excellence, 15(2), 70-89.

65) Steiner, G. A., \& Steiner, J. F. 1980. Business, government, and society: A managerial perspective. New York: Random House Business Division.

66) Stevenson, M. and Spring, M. 2007. Flexibility form a supply chain perspective: definition and review, International Journal of Production Management, 27(7), 685-713.

67) Swaminathan, J.M., 2006. Managing Supply Chain Operations in India - Pitfalls and opportunities, Building Supply Chain Excellence in Emerging Economies, Springer Science + Business Media LLC.

68) Swanson R.A. 1995. Performance Is The Key. Human Resource Development ,6(2)207-213.

69) Tang, T.L.P. 2010. From increasing gas efficiency to enhancing creativity: it pays to go green. Journal of Business Ethics, 94 (2), 149-55.

70) Vachon, S., \& Klassen, R.D. 2006. Extending green practices across the supply chain: the impact of upstream and downstream integration. International Journal of Operations $\mathcal{E}$ Production Management, 26(7), 795-821.

71) Webster, S. 2006. Auto industry survey: execs' outlook sours as volatility increases, uncertainty creates foothold for pessimism. Knight Ridder Tribune Business News, p. 1.

72) Willard M, Darcy Hitchcock. 2009. The Business Guide to Sustainability Practical Strategies and Tools for Organizations

73) Wolf, J. 2014. The Relationship Between Sustainable Supply Chain Management, Stakeholder Pressure and Corporate Sustainability Performance. J Bus Ethics (119), 317-328

74) Womack, J.P., \& Jones, D.T. 2005. Lean solutions: How companies and customers can create wealth together. The Free Press, New York, NY.
75) Wong, H., Cattrysse, D., \& Van, O. D. 2005. Stocking decisions for repairable spare parts pooling in a multi-hub system. International Journal of Production Economics, 93/94, 309-317.

76) Yaziji, M. 2004. Turning gadflies into allies. Harvard Business Review, 82(2), 110-115.

77) Yu Xia, Thomas Li-Pin Tang. 2011. Sustainability in supply chain management: suggestions for the auto industry, Management Decision, 49 (4), $495-512$

78) Zhang, H.C., Kuo, T.C., Lu, H., \& Huang, S.H. 1997. Environmentally conscious design and manufacturing: a state-of-the-art survey. Journal of Manufacturing Systems, 16, 352-71.

79) Zhu, Y.J. \& Deshmukh, A. 2003. Application of Bayesian decision networks to life cycle engineering in green design and manufacturing. Engineering Applications of Artificial Intelligence, 16, 91-103.

80) Zhu, Q. \& Sarkis, J. 2004. Relationships between operational practices and performance among early adopters of green supply chain management practices in Chinese manufacturing enterprises. Journal of Operations Management, 22(3), 265-289.

81) Zhu, Q., Sarkis, J., \& Lai, K. 2007a. Green supply chain management: pressures, practices and performance within the Chinese automobile industry. Journal of Cleaner Production, 15, 10411052.

82) Zhu, Q., Sarkis, J., \& Lai, K. 2007b. Initiatives and outcomes of green supply chain management implementation by Chinese manufacturers. Journal of Environmental Management, (85), 179-89.

83) Zhu, Q., Sarkis, J., \& Lai, K.H. 2008b. Green supply chain management implications for 'closing the loop'. Transportation Research Part E. Logistics and Transportation Review, 44(1), 1-18. 